\title{
Mycosis in the Stomach Compartments of Cattle
}

\author{
By Henrik Elvang Jensen, Axel Basse and Bent Aalboek \\ Department of Veterinary Pathology and Department of Hygiene and Microbiology. \\ Royal Veterinary and Agricultural University, Denmark.
}

\begin{abstract}
Jensen, H. E., A. Basse and B. Aalbæk: Mycosis in the stomach compartments of cattle. Acta. vet. scand. 1989, 30, 409-423. - During a period of 22 months, 9.7\% (23 out of 238) of the cattle necropsied at the Department of Veterinary Pathology had mycotic affections in the stomach compartments.

The various stomach compartments were affected in the following pattern: omasum: 15 cases, rumen: 10 cases, reticulum: 8 cases and abomasum: 6 cases. In 5 of the animals myotic affection was also found in other organs of which the liver was most often involved.

Out of the 23 cases described, a primary diagnosis of mycosis was only established in 5 cases. In the remaining 18 cases the mycotic infection was regarded as being of a minor importance in the total necropsy result.

Macroscopically and histologically the mycotic processes could be grouped into acute, subacute or chronic affections. In 20 cases only one type of inflammation was present, in the remaining cases combinations were found.

Identification of the infective agent was performed by immunological staining of hyphal structures in tissue sections. Members of the Zygomycetes were found to predominate as causative fungi. Aspergillus fumigatus was found to have a propensity for infecting the terminal gastric compartments, whereas the Zygomycetes were found regularly in all compartments. Candida spp. were only found in 1 case. Predisposing factors for developing systemic mycosis are discussed. Among these especially the use of antimicrobial drugs, other diseases, metabolic disturbances and stressors in the post parturient period seem to be important.
\end{abstract}

aspergillosis; zygomycosis; candidosis; forestomachs; cattle diseases.

\section{Introduction}

In an attempt to unify the terminology of mycosis in man and animals, systemic mycosis (endomycosis) has been defined as mycotic infections in internal organs (Kielstein et al. 1987). In this concept it is also agreed that systemic infections with Candida spp. should be termed candidosis; systemic infections with Aspergillus spp. should be termed aspergillosis and infections due to the order Mucorales of the Zygomycetes should be termed mucormycosis. Infection with Zygomycetes is termed zygomycosis (Chandler et al. .1980).
In a review of the world literature concerning systemic zygomycosis and aspergillosis in cattle showing clinical signs of disease, Sheridan (1981) found the abomasum to be the most often reported site of mycotic lesion of the stomach compartments.

Members of the Zygomycetes order Mucorales, such as the genera Mucor, Absidia and Rhizopus, have been shown to be the predominant agents in the systemic mycotic infections in the stomach compartments of cattle (Gitter \& Austwick 1957, Pohlenz et al. 1973, Neitzke \& Schiefer 1974, Watanabe et al. 1979). 
Infections with Candida albicans, candidosis s. moniliasis, have been reported in all stomach compartments too (Gitter \& Austwick 1957, Topolko et al. 1967, Mills \& Hirth 1967).

The paper of Werdin et al. (1980) seems to be the first report of aspergillosis in the forestomach compartments of adult cattle. In contrast, occurrence of aspergillosis in the abomasum has been reported several times (Pinsent \& Ritchie 1955, Wray \& Tomlinson 1968, Anon 1971-72, Hatziolos 1973). From these reports it is obvious that especially calves are susceptible to aspergillosis in the abomasum.

Generally, reports of systemic fungal infections in cattle can be placed in 3 main groups: 1) forms where the mycotic infection is the overall cause of sickness and, in many cases, death of the animal (Cordes et al. 1964b, Pohlenz et al. 1973, Ohshima et al. 1976, Watanabe et al. 1979, Werdin et al. 1980, Doherty \& Markey 1987); 2) chronic granulomatous and/or asteroid-producing infections, usually found in the lymphatic system and lung by routine meat control or in apparently normal lymph nodes (Gleiser 1953, Davis et al. 1955, Eggert \& Romberg 1960, Austwick 1962a, Angus et al. 1973) and 3) abortion due to mycotic placentitis (Smith 1920, Bendixen \& Plum 1929, Schifer 1967, Cordes \& Shortridge 1968, Ainsworth \& Austwick 1973, Krogh 1985, McCausland et al. 1987). Most reported cases are related to group 3, dealing with the mycotic abortion in cattle.

The aim of this article is to report clinical and describe post mortem pathological findings in 23 cattle with systemic mycosis primarily affecting the stomach compartments. Mycological cultivation was attempted in 12 of the cases.

The cases were obtained by routine post mortem examination of 238 cattle during a period of 22 months in 1986-1987 at the Department of Veterinary Pathology, Royal Veterinary and Agricultural University, Denmark.

\section{Material and methods}

From February 1986 to December 1987 necropsy was performed on a total of 238 cattle at the Department of Veterinary Pathology. Most of the necropsied cattle either died or were euthanized at the Department of Surgery or the Department of Internal Medicine of the University.

Detailed observation was performed at necropsy. Particular attention was paid to the examination of the stomachs. Care was taken to include every single lamina of the omasum by the washing procedure. The dissection technique for examination of the bovine forestomachs has been described in detail elsewhere (Jensen 1988).

Tissue specimens for histological examinations were taken from affected stomach compartments and relevant organs. In 9 cases this included the corresponding lymph nodes. Sections were fixed in $10 \%$ buffered neutral formalin and from paraffin blocks 5 $\mu \mathrm{m}$ sections were made. Routinely these were stained with haematoxylin and eosin (H\&E) and periodic acid-Schiff (PAS). In several cases sections were also subjected to Grocott's methenamin-silver technique (GMS) and Graidley's stain for fungi.

Pizzolato's stain was used in order to demonstrate calcium oxalate crystals.

In all cases the diagnosis of mycosis was made by histological demonstration of hyphae in the tissues obtained post mortem. The aetiological diagnosis was accomplished by immunological staining. The method has been described in detail elsewhere (Jensen \& Schønheyder 1989).

In 12 cases tissue sections were collected for mycological cultivation, in 4 cases this inclu- 
ded the corresponding lymph nodes. Mycological cultivation was routinely performed on Sabouraud dextrose agar (Difco 010901 ), incubated at $37^{\circ} \mathrm{C}$ and $25^{\circ} \mathrm{C}$ for 7 days.

\section{Results}

Systemic mycosis was diagnosed in a total of 23 cattle by routine necropsy of 238 cattle in a 22-month-period (1986-87) corresponding to $9.7 \%$.

In Tables 1 and 2 the main clinical and pathological findings are given. Mycotic infections were found in 4 bulls and 19 cows. Of the cows 11 were in the post puerperal period and 3 were pregnant. Ages from 0.5 to over 7 years were represented. Most animals (87\%) were 2 years old or more.

None of the cases had been recognized as mycosis before post mortem examination. Symptoms from the gastro-intestinal tract, such as diarrhoea, melaena and ruminal atony, were observed in 12 cases $(52 \%)$. Unspecific clinical signs were apathy, anorexia and fever. Other signs were related to underlying diseases, the most common of which were: mastitis (11 cases, of which 5 were necrotizing), fatty liver changes (9 cases), endometritis ( 5 cases) and mucosal disease ( 3 cases). Rumen putrefication and stasis were each found in 1 case. Only 1 case (number 20) had

Table 1. Findings in 23 cattle with systemic mycosis.

\begin{tabular}{|c|c|c|c|c|c|c|c|}
\hline $\begin{array}{l}\text { Case } \\
\text { number }\end{array}$ & Sex & $\begin{array}{l}\text { Age in } \\
\text { years }\end{array}$ & $\begin{array}{l}\text { Duration } \\
\text { of llness }\end{array}$ & $\begin{array}{l}\text { Status of } \\
\text { pregnancy }\end{array}$ & $\begin{array}{l}\text { Signs from } \\
\text { GI-canal }\end{array}$ & Therapy & $\begin{array}{l}\text { Main clinical and necropsy } \\
\text { findings without } \\
\text { mycotic involvement }\end{array}$ \\
\hline 1 & $\mathbf{F}$ & 2.5 & 10 days & pregnant & + & + & Fatty liver, rumen putrefaction \\
\hline 2 & $\mathbf{F}$ & $>4$ & 5 weeks & 5 weeks p.p. & + & + & Fatty liver, mastitis, endometritis \\
\hline 3 & $\mathrm{~F}$ & $>2$ & 10 days & 17 days p.p. & + & + & Fatty liver, downer, necro. mastitis \\
\hline 4 & $\mathbf{F}$ & $>4$ & 7 days & 11 days p.p. & + & + & Downer, necro. mastitis \\
\hline 5 & $\mathbf{M}$ & 1.0 & $>5$ days & - & + & + & Mucosal disease \\
\hline 6 & $\mathbf{M}$ & 0.5 & $>8$ days & - & - & + & Pneumonia \\
\hline 7 & $\mathrm{~F}$ & 7.0 & 10 days & not pregnant & - & + & Fatty liver, necro. mastitis \\
\hline 8 & $\mathbf{M}$ & 2.0 & 6 days & - & + & + & Uraemia, cystitis, ascites \\
\hline 9 & $\mathbf{F}$ & $>2$ & 8 days & 8 days p.p. & - & $?$ & Fatty liver, downer, mastitis \\
\hline 10 & $\mathbf{F}$ & $>2$ & 12 days & 12 days p.p. & + & + & Fatty liver, downer, mastitıs \\
\hline 11 & $\mathbf{F}$ & 2.5 & $>7$ days & 4 weeks p.p. & + & + & Mucosal disease \\
\hline 12 & $\mathbf{F}$ & 2.0 & $>12$ days & not pregnant & - & + & Endocarditis, pneumonia \\
\hline 13 & $\mathbf{F}$ & 3.0 & 5 weeks & 5 weeks p.p. & + & + & Necro. mastitis, arthritis \\
\hline 14 & $\mathbf{F}$ & 4.0 & 3 weeks & 3 weeks p.p. & - & + & $\begin{array}{l}\text { Fatty liver, endometritis, } \\
\text { ketonaemia }\end{array}$ \\
\hline 15 & $\mathbf{F}$ & $>2$ & $>7$ days & not pregnant & - & + & Pneumonia, endometritis, mastitis \\
\hline 16 & $\mathbf{F}$ & 1.5 & 15 days & not pregnant & + & + & Mucosal disease \\
\hline 17 & $\mathbf{F}$ & 6.5 & $>1$ day & pregnant & - & + & Endometritis \\
\hline 18 & $\mathrm{~F}$ & 6.5 & 15 days & not pregnant & - & $?$ & Rumen stasis, pneumonia \\
\hline 19 & $\mathbf{M}$ & 2.0 & 6 days & - & + & + & None \\
\hline 20 & $\mathbf{F}$ & 3.0 & 7 days & pregnant & + & + & None (history of grain overload) \\
\hline 21 & $\mathbf{F}$ & $>4$ & 9 days & 24 days p.p. & - & + & Fatty liver, necro. mastitis \\
\hline 22 & $\mathrm{~F}$ & $>4$ & 8 days & 7 days p.p. & - & + & Polyarthritis, necro. mastitis \\
\hline 23 & F & $>2$ & $?$ & ? days p.p. & - & + & Fatty liver, endometritis, mastitis \\
\hline
\end{tabular}

"Therapy« refers to treatment with antimicrobial and/or antiinflammatory drugs.

Abbreviations: F: female; M: male; p.p.: post partum; necro.: necrotizing. 
Table 2. Findings in 23 cattle with systemic mycosis.

\begin{tabular}{|c|c|c|c|c|c|c|c|}
\hline \multirow{2}{*}{$\begin{array}{l}\text { Case } \\
\text { number }\end{array}$} & \multicolumn{5}{|c|}{ Histological location of fung1 } & \multirow{2}{*}{$\begin{array}{l}\text { Immunological } \\
\text { classification } \\
\text { of involved fungus } \\
\text { in lesion(s) }\end{array}$} & \multirow{2}{*}{$\begin{array}{l}\text { Mycological } \\
\text { result }\end{array}$} \\
\hline & Rumen & Retıculum & Omasum & Abomasum & Other organs & & \\
\hline 1 & & & a & & & $\begin{array}{l}\text { Zygomycetes } \\
\text { Asp. fum. }\end{array}$ & nd \\
\hline 2 & ch & ch & ch & & kidneys(ch) & Zygomycetes & nd \\
\hline 3 & & & a & & & Zygomycetes & negative \\
\hline 4 & & & sa, ch & & & Asp. fum. & nd \\
\hline 5 & a & & a & a & & $\begin{array}{l}\text { Zygomycetes } \\
\text { Asp. fum. } \\
\text { Candida spp.* }\end{array}$ & negative \\
\hline 6 & ch & & & & & Zygomycetes & negative \\
\hline 7 & $\mathrm{a}$ & a & a & a & $\begin{array}{c}\text { liver, spleen, } \\
\text { lung, diaphragm(a) }\end{array}$ & Asp. fum. & $\begin{array}{c}\text { Mucorales } \\
(2,3)\end{array}$ \\
\hline 8 & & & & a & & Zygomycetes & nd \\
\hline 9 & & & a & & & Asp. fum. & nd \\
\hline 10 & a & a & a & & liver(a) & Asp. fum. & $\begin{array}{c}\text { Mucorales } \\
\text { (4) }\end{array}$ \\
\hline 11 & & & a & & & Zygomycetes & negative \\
\hline 12 & & sa & & & & Zygomycetes & nd \\
\hline 13 & & & ch & & & Zygomycetes & nd \\
\hline 14 & & & a & & & Asp. fum. & $\begin{array}{l}\text { Asp. fum. } \\
\text { (4) }\end{array}$ \\
\hline 15 & a & a & & & & Zygomycetes & $\begin{array}{c}\text { Mucorales } \\
(1,2)\end{array}$ \\
\hline 16 & & sa & & & & Zygomycetes & nd \\
\hline 17 & & a & & & & nd & nd \\
\hline 18 & a & & & & & nd & nd \\
\hline 19 & a & a & a & a & jejunum(ch) & Zygomycetes & $\begin{array}{c}\text { Mucorales } \\
\text { (1) }\end{array}$ \\
\hline 20 & & & a & & & Zygomycetes & negative \\
\hline 21 & sa & & sa & a & & Zygomycetes & $\begin{array}{c}\text { Mucorales } \\
\text { (3) }\end{array}$ \\
\hline 22 & & & a & a & liver(a) & $\begin{array}{l}\text { Zygomycetes } \\
\text { Asp. fum. }\end{array}$ & negative \\
\hline 23 & ch & & & & & Zygomycetes & nd \\
\hline Total & 10 & 8 & 15 & 6 & 5 & & \\
\hline
\end{tabular}

Abbreviations: nd: not done; Asp. fum.: Aspergillus fumigatus; a: acute; sa: subacute; ch: chronic; 1: rumen; 2 : reticulum; 3: omasum; 4: liver; *: classification based on morphology.

a history of grain overload prior to the onset of sickness.

Antimicrobial drugs (20 cases) and/or antiinflammatory drugs such as corticosteroids ( 2 cases) and flunixin meglumin ( 8 cases) had been administered in 21 cases. In the remai- ning 2 cases no information about treatment was available. In 20 cases the time from onset of disease to death or euthanasia was short (few days-2 weeks). In 2 cases this interval was 5 weeks. In 1 case no information was available. 
By the immunological identification of hyphae, 13 animals were found to be exclusively affected by Zygomycetes, whereas 5 animals were found to be infected with Aspergillus fumigatus. In 3 animals dual infection with Zygomycetes and Aspergillus fumigatus was diagnosed. In one of these, Candida species were also seen.

Mycotic lesions in the stomach compartments were distributed in the following pattern: rumen: 10 cases; reticulum: 8 cases; omasum: 15 cases; and abomasum: 6 cases. Infections in other organ systems were found in 5 cases. In 4 cases only a single organ system outside the stomachs was infected, distributed as follows: liver, 2 cases; kidneys, 1 case; jejunum, 1 case. In 1 case (no. 7) mycotic infections outside the stomach compartments were found in the lung, liver, diaphragm and spleen.

No spread of hyphae to any of the lymph no- des examined had occurred. The reaction in the nodes, if any, was limited to follicular proliferation, some edema and occasionally a small increase in the number of medullary plasma cells.

At macroscopic and histological examination the lesions were grouped into acute, subacute and chronic affections. In 20 cases only one state of inflammation was present, of these 14 were acute, 2 subacute and 4 chronic. Combined inflammatory states were found in 3 cases, 1 case of each combination was found: acute and subacute; acute and chronic; subacute and chronic.

\section{Gross necropsy findings}

Macroscopically the acute forms were in all cases characterized by haemorrhagia and necrosis. In most cases the central necrotic area - in some cases covered by fibrin - was surrounded by a haemorrhagic demarcation

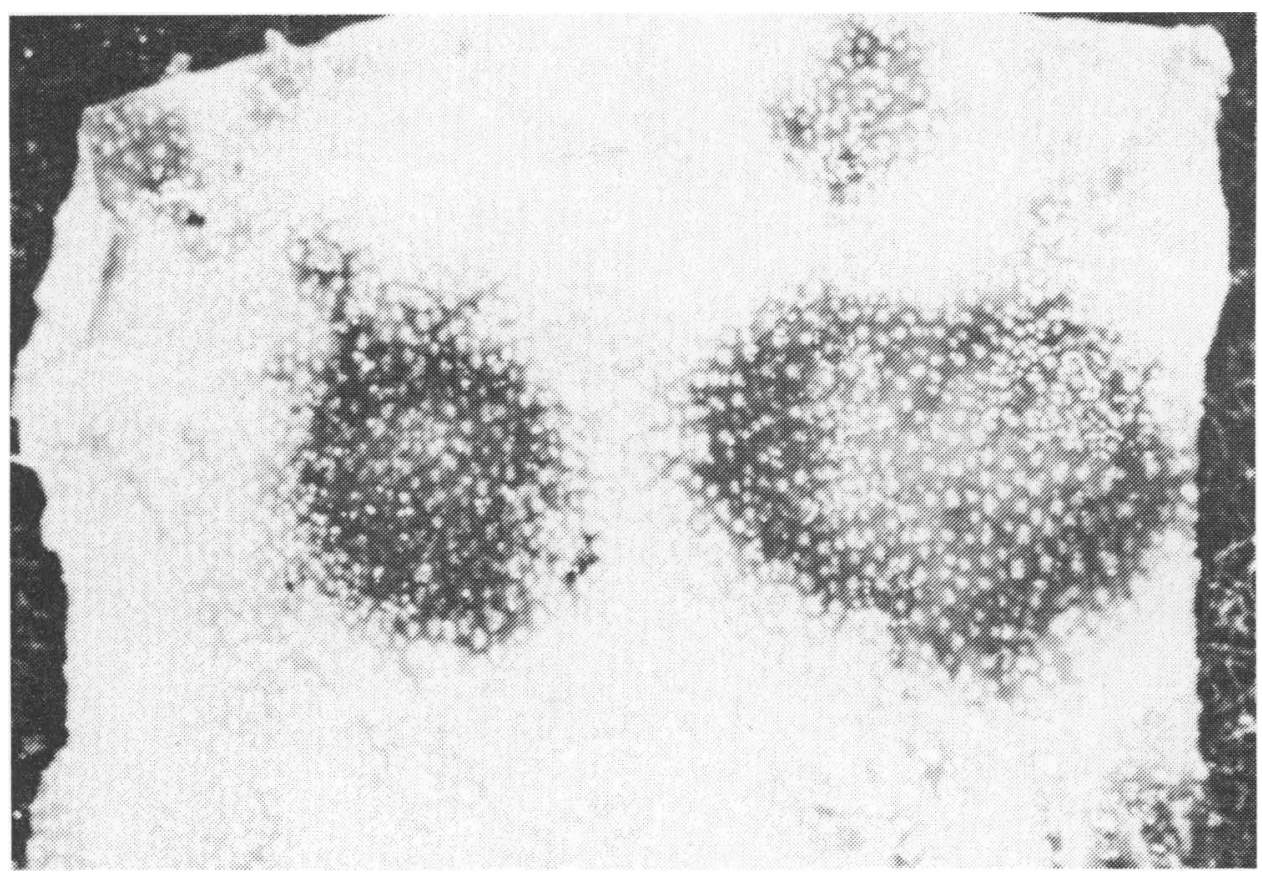

Figure 1. Acute mycotic omasitis. (Case no. 5). 
zone (Fig. 1). In the laminae of the omasum this feature was a constant finding in affections measuring above $1 \mathrm{~cm}$ in diameter. The number of affected laminae in the omasum varied from 2 to almost all. The size of affected areas varied from very small concentric processes with diameters down to approximately $0.3 \mathrm{~cm}$ and up to involving almost all of the stomach compartments. The latter was seen in cases number 5, 7, 8, 10 and 19 . In these cases, where the affected walls were 1-2 times thicker than normal due to fibrin exudation and edema, the haemorrhagic necrosis in some areas extended to the serosal surface, where a haemorrhagic fibrinous peritonitis was present. Transplantatory mycotic metastasis to adjacent stomach compartments could be seen.

Acute affections of other organ systems were likewise characterized by haemorrhagic necrosis. In the liver 2 types were seen; in ca- ses number 10 and 22 the necrotic areas consisted of disseminated, small, haemorrhagic areas of variable shape. In case number $7 \mathrm{nu}$ merous large, globular, dry, firm and haemorrhagic necrotic affections surrounded by a distinct haemorrhagic zone were found (Fig. 2). In locations where the lesions extended to the surface they were covered by fibrin, and transplantatory metastasis to the diaphragm had been established. In the same case (number 7) the disseminated affections in the lung and spleen had the appearance of dry fibrino-haemorrhagic necrosis.

The lesions in these organs, too, had a globular appearance with diameters ranging from $0.3-3 \mathrm{~cm}$, the largest of which were found in the spleen.

The subacute form was found only in the forestomachs. Macroscopically all lesions were to some degree covered by brown or brown-red necrotic material. In the omasum

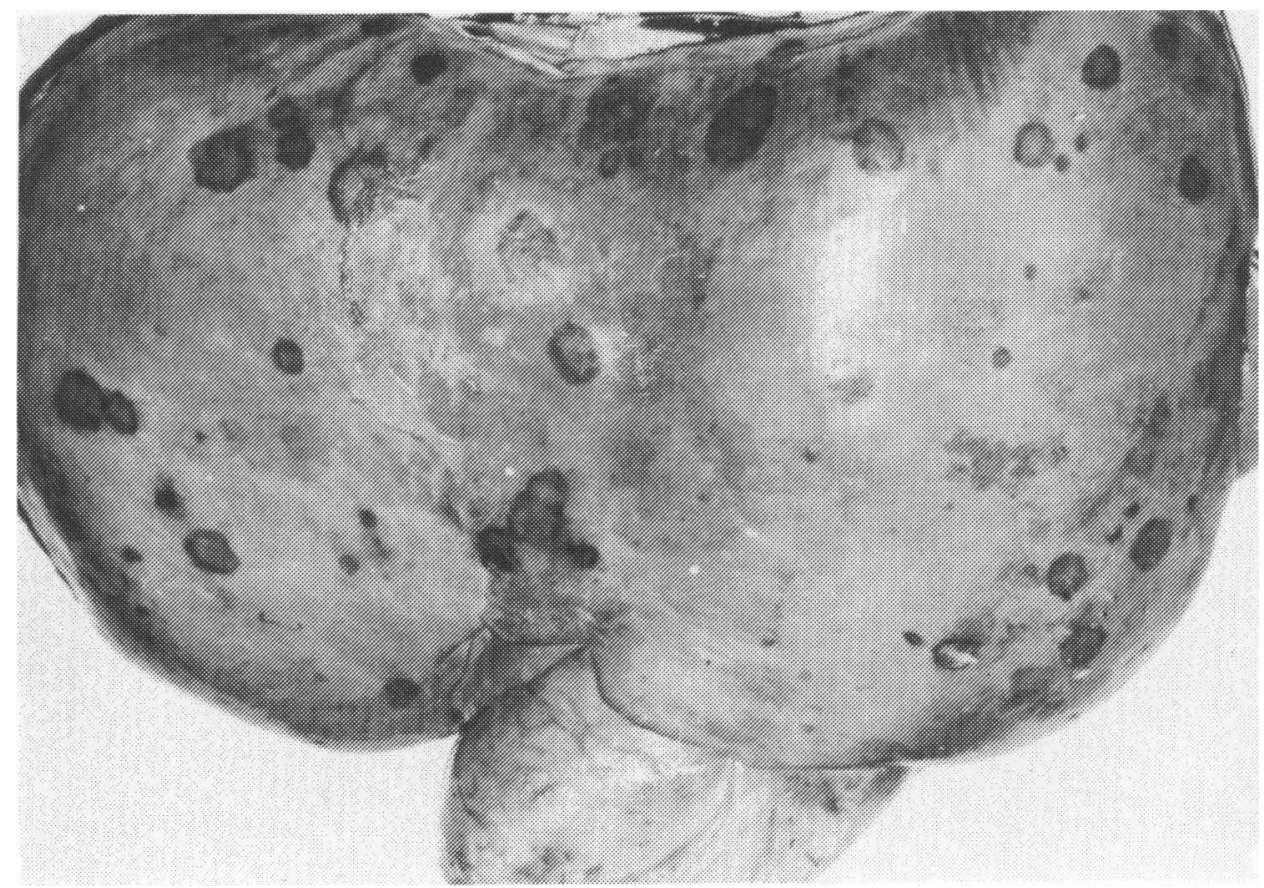

Figure 2. Acute mycotic hepatitis. (Case no. 7). 
lesions appeared as circumscript affections consisting of brownish necrotic tissue. In some cases the central necrotic tissue had fallen out, leaving the affections as fenestrations of the laminae. In such cases only a thin rim of brown necrotic masses was left covering the edges of the fenestrations. In the subacute necrotic states haemorrhage was seen only to a limited extent or not at all. In the reticulum the subacute necrotizing lesions were either found - as in case number 16 - as a single circumscript affection with a diameter of $2.5 \mathrm{~cm}$, or - as in case number 12 - as multiple focal, brown, necrotizing lesions measuring from $0.1-0.3 \mathrm{~cm}$ i diameter. In case number 21 the ruminal affections consisted of 2 concentric necroses in the caudo-dorsal sac. All the subacute affections were demarcated from the surrounding tissue and none had progressed to the parietal surface.

In the rumen and reticulum all chronic affections had a yellow-brown, smooth, unepithelialized central part. This was surrounded by a rim of newly formed epithelium, covering a granulation tissue, with varying degrees of contraction. On the cutting surface, the affections were yellow-gray and firm. Disseminated necrotic/purulent foci in the granulation tissue were seen in case number 6 and 23. In case number 6 these foci fistulated to the unepithelialized, smooth surface. The chronic affections varied from app. $1 \times 1 \mathrm{~cm}$ to $4 \times 6 \mathrm{~cm}$. In cases number 4 and 13 the affections of the omasum consisted of multiple epithelialized fenestrations of the laminae. The diameter of these varied from $0.5-2.0 \mathrm{~cm}$. The edges of the fenestrations were slightly elevated and had a gray-whitish color in comparison with the surrounding dark-brown epithelium.

Outside the forestomachs chronic mycotic infections were only found in kidneys (case number 2 ) and in the jejunum (case number
19). Macroscopically, the renal affections had the appearance of chronic infarcts. The lesions in the jejunum were macroscopically characterized by submucosal miliary abscesses.

\section{Histopathological findings}

The acute lesions were characterized by pronounced haemorrhage, fibrin exudation and necrosis. Thrombosis of the vascular lumen was also a constant finding.

In the central part of omasal affections the thrombosis affected both arteries and veins, whereas in the haemorrhagic border zone it was mostly confined to the veins. Outside the haemorrhagic border zone only veins were thrombosed. Only in some of these hyphae were found. The central area of the omasal affections had the appearance of a coagulation necrosis, since all structures including the thrombosed vessels and hyphae, had the same eosinophilic, necrotic appearance. Typically, there were no cellular infiltration in these central areas of the necrosis. A constant finding was the infiltration with inflammatory cells, dominated by heterophilic granulocytes. The cellular infiltration was mainly associated with hyphal structures both in the tissue and thrombosed vessels containing hyphae. The muscular structures were frequently the most heavily infiltrated tissues with respect to inflammatory cells around hyphae. Only subsequent to infiltration by heterophilic granulocytes, substantial tissue necrosis became apparent (Fig. 3). Fibrin exudation, especially in the lamina propria, and vein congestion were common findings in the haemorrhagic border zones. The acute reactions in the other stomach compartments and organ systems had the same composition as those described in the omasal laminae. With some modifications the following changes were constant fin- 


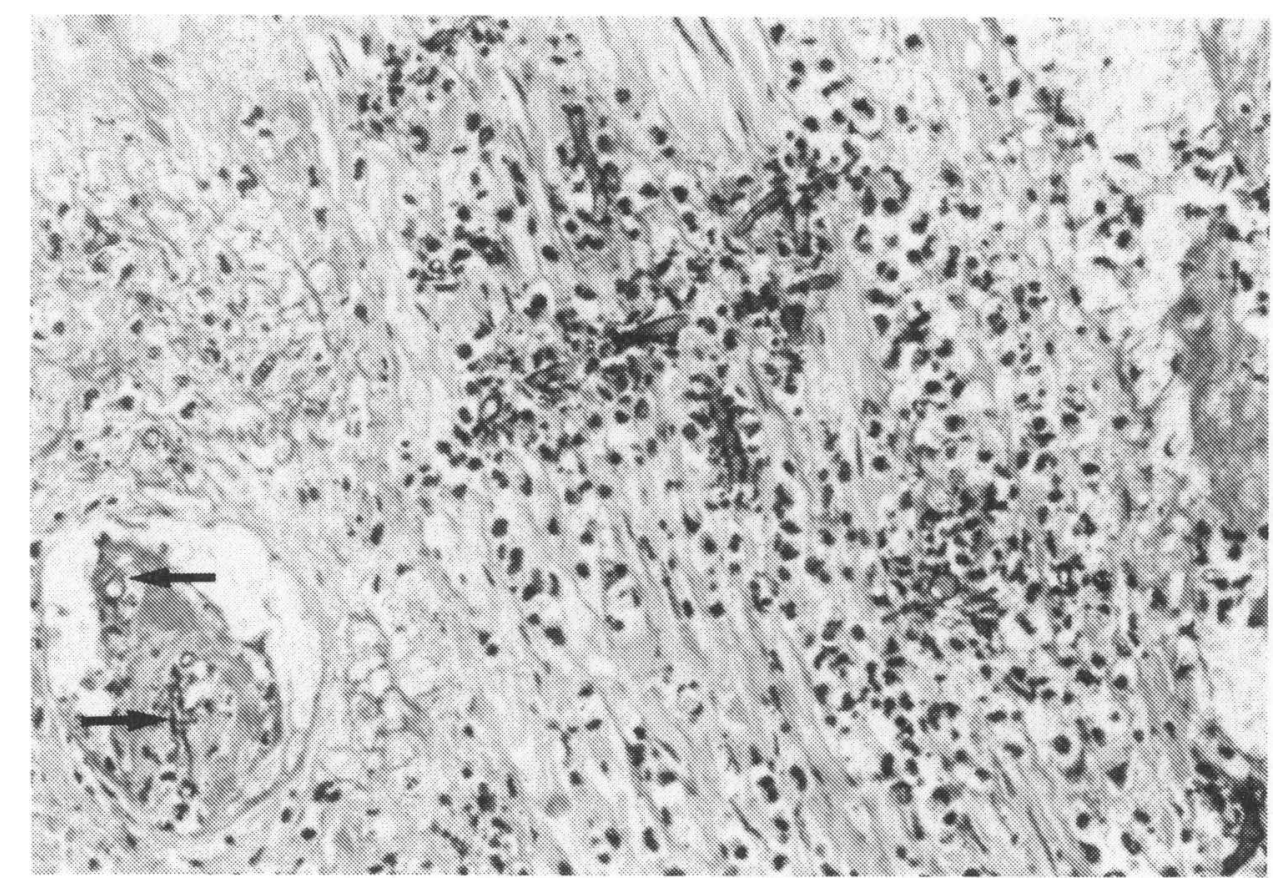

Figure 3. Acute mycotic, haemorrhagic, necrotic and purulent omasitis. Hyphae are seen in a thrombosed vein $(\rightarrow)$ and in lamina muscularis. (Case no. 3. PAS. Obj. X 25).

dings in all cases: necrosis, haemorrhage, thrombosis, vein congestion, cellular infiltration - mainly granulocytes, fibrin exudation both in tissue and on surfaces. In cases where necrosis had progressed to the parietal surface, hyphae could sometimes be seen in fibrin exudate at this site. In case number 7 this was found on the rumen, liver and diaphragm.

The necrotic affections in the liver and spleen in case number 7 were accompanied by deposition of a massive quantity of birefringent crystals morphologically and histochemically compatible with calcium oxalate (Pizzolato positive).

In subacute lesions the necrotic areas were demarcated from the viable tissue by newformed loose granulation tissue and/or polymorph and mononuclear cells. In case number 16 sinus formation had been produced by epithelial undergrowth of the necrotic areas. Cases number 4 and 21 showed a beginning demarcation of the central necrotic areas in the omasal laminae by a simultaneous ingrowth of the epithelial lining from both sides of the laminae, thereby expelling the whole necrosis including the hyphal elements (Fig. 4). Further progress of this phenomenon was found as epithelialized borders in fenestrations. In these, there were proliferations of granulation tissue, edema, cellular infiltration and thrombosed vessels in the lamina propria. In the walls of thrombosed vessels edema and some fibroblast proliferation were found. In case number 4 no hyphae could be demonstrated on the viable side of the demarcation zone or in the epithelialized edges of newly formed fene- 


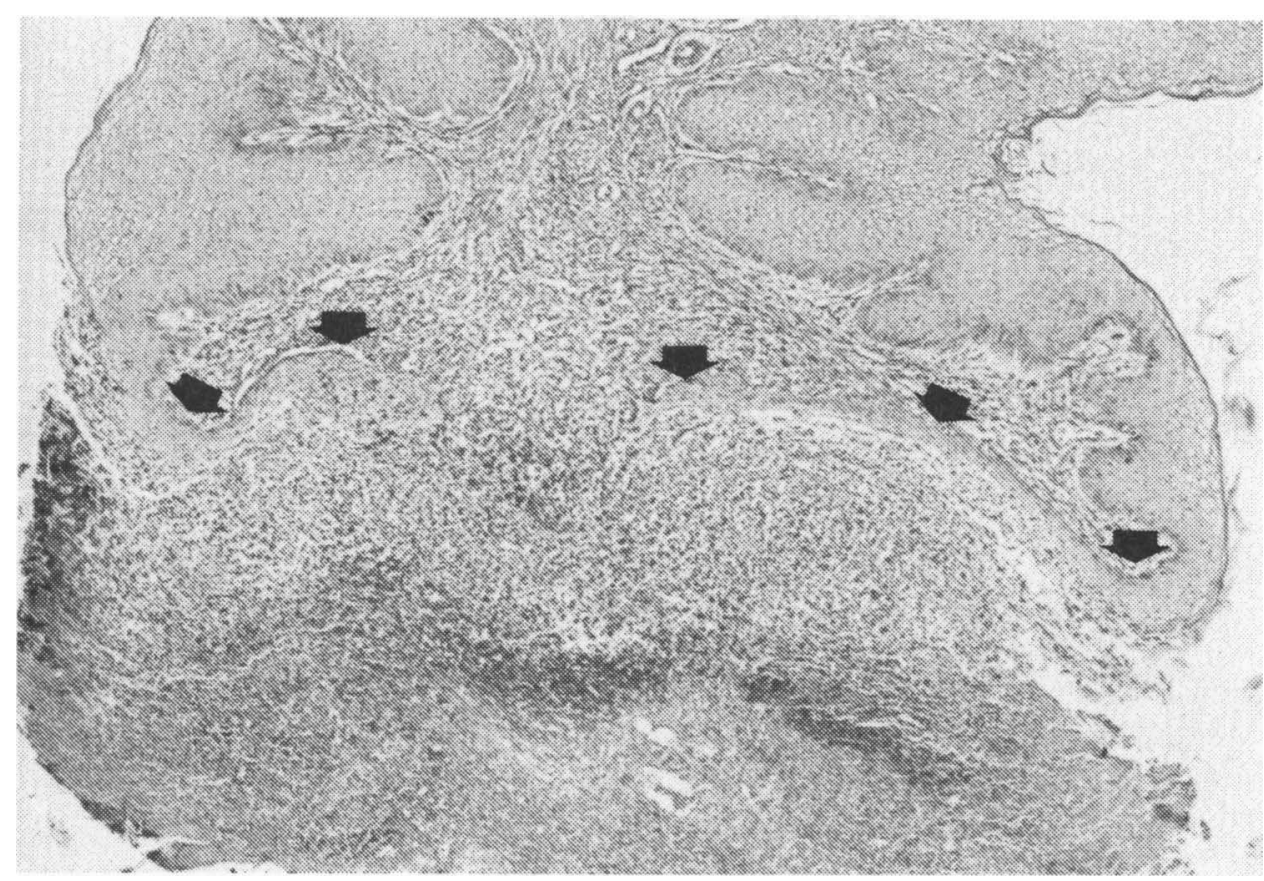

Figure 4. Subacute mycotic omasitis. The necrotic tissue is demarcated by simultaneous ingrowth of the epithelial lining $(\rightarrow)$. (Case no. 4. PAS. Obj. X 2.5).

strations in the omasum. In both cases number 12 and 21 the necrotic processes of the subacute stage were demarcated by newly formed loose granulation tissue and mononuclear cells. In case number 12 the mononuclear cells were of the macrophage type, whereas in case number 21 they were more resembling the epithelioid type. In case number 21 thrombosed vessels, hyphae and necrosis were found on both sides of the demarcation zone.

In all cases, except in the jejunum in case number 19 , chronic mycotic infections were characterized by granulomatous inflammation. In case number 19 the affections in the jejunum consisted of dilated crypts with accumulation of purulent material. In the pus, hyphae with and without asteroid formation were seen. In 4 cases regular granulomas had formed. In these, the central part consisted of polymorphonuclear leukocytes and hyphae. In case number 2 (kidneys) and in case number 6 (rumen) the central part consisted of necrotic tissue, accumulation of polymorphonuclear leukocytes, and hyphae. In the 2 other cases - number 13 (omasum) and number 23 (rumen) - the central area consisted of loosely built connective tissue infiltrated with few inflammatory cells including epithelioid and giant cells. Hyphal structures were occasionally found in the giant cells (Fig. 5). Surrounding the central masses zones were built up by lymphocytes, plasma cells, epithelioid and giant cells, which consisted of both the Langerhans and foreign-body type, predominated by the former. Around the granulomas connective tissue had developed to a variable extent. In this 


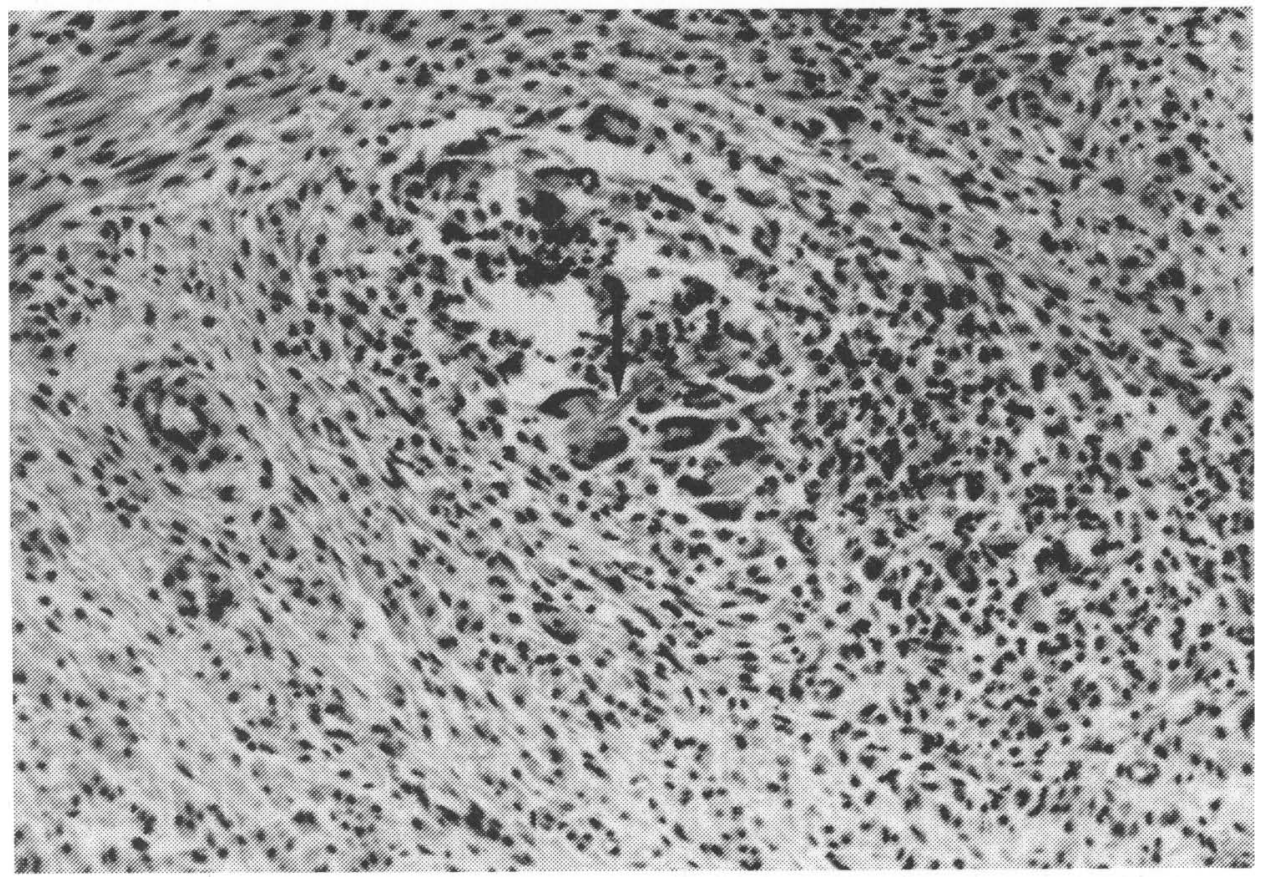

Figure 5. Chronic mycotic omasitis. In the granuloma a hypha $(\rightarrow)$ within giant cells is seen.

(Case no. 13. H\&E. Obj. X 10).

connective tissue giant cells, lymphocytes and polymorphonuclear cells were found in different numbers. The forestomach affections in case number 2 consisted of heavy granulation tissue formation with dystrophic calcification of hyphal fragments and elastic fibres in vessels and connective tissue. Around the calcified structures numerous giant cells were found. In 3 cases $(6,13$ and 19) eosinophilic asteroid bodies covered some of the hyphae. In cases number 6 and 13 the asteroid bodies were positive in the PAS-staining, whereas they were negative in case number 19.

In the corresponding lymph nodes examined, neither hyphae nor inflammation due to mycosis were found.

\section{Microbiological examination}

Only 6 of the 12 cases, in which tissue samples were examined microbiologically, yielded fungal growth on cultivation. In 5 cases the isolated fungi showed morphological characteristics of Mucorales. In case number 4 Aspergillus fumigatus was cultivated from liver tissue. However, mycotic hepatitis was not confirmed by the histological examination, although the macroscopic examination revealed some small blood accumulations which were considered to represent the acute form of mycotic hepatitis.

None of the attempts of cultivation from regional lymph nodes yielded positive results. The microbiological results are listed in Table 2 . 


\section{Discussion}

On the examination of the stomach compartments of cattle, the omasum was found to be the predominant site of mycotic lesions. This is in agreement with the results obtained by Basse (1974).

The results support the view that Zygomycetes are the most common cause of fungal infections in the stomach compartments of cattle. As single agent, Zygomycetes were found in 13 of the cases and Aspergillus fumigatus in 5 cases. A combination of Zygomycetes and Aspergillus fumigatus was found in 3 cases. Candida spp. were only found in 1 case, in mixed infection with Aspergillus fumigatus and Zygomycetes.

The above-mentioned fungi are all opportunistic pathogens and ubiquitous agents. Aspergillus spp. and Mucorales are often found in soil and hay (Austwick 1962b) and Candida albicans can be found on clinically normal mucous membranes (Mills \& Hirth 1967). Especially the Mucorales are reported as a frequent inhabitant in the rumen contents of normal ruminants (Rolle \& Kolb 1954, Holtenius \& Nielsen 1957).

To establish an infection, an opportunistic pathogenic agent requires a disturbance in the equilibrium between the infectant and the infected animal. Such a disturbance may be a high rate of exposure to the fungi (Austwick 1962b, Alnsworth \& Austwick 1973) or a favouring of its growth either directly or indirectly by treatment of the host with antimicrobial drugs (Cross et al. 1970, Emmons et al. 1977). Of the 23 cases in this survey, there was no history of feeding mouldy hay or other highly contaminated foodstuffs, but in 20 cases the patients had been treated with antimicrobial drugs.

A declining defence mechanism due to a damage of the epithelial lining in the forestomachs, as found in rumen acidosis, has been reported on several times (Thomson 1967,
Miller 1976, Chihaya et al. 1988). Predisposition due to acidosis was only found in case number 20.

Likewise, IBR erosions in the forestomachs have been assumed as portal of entry for mycotic invasion (Neitzke \& Schiefer 1974). In 3 cases (numbers 5, 11 and 16) a diagnosis of Mucosal disease was established in combination with the mycotic infection, which in these cases was acute to subacute and limited to the forestomachs. This leads to the assumption that this viral erosive disease could act as a predisposing factor for mycotic invasion, either by producing erosions in the mucosal lining of the forestomachs or due to its immunosuppressive effect. In one case (number 8) uraemic ulceration in the epithelial lining of the forestomachs may have disposed for mycotic invasion.

Finally, any immunodeficient or immunosuppressive condition of the host, whether it comes from corticosteroid therapy, infections, metabolic disturbances or stress, might facilitate the establishment of the mycotic infection (Sheldon \& Bauer 1962, Schifer 1967, Emmons et al. 1977, Munro et al. 1985). To this category at least 2 cases that had received corticosteroid therapy can be related. In 1 of these cases antimicrobial drugs had been administered, too. In the 8 cases where flunixin meglumin had been used, it was always in combination with antimicrobial drugs, so no conclusion about its effect in enhancing the risk of acquiring mycotic infections can be drawn from the present material.

In a least 11 cases the host was in the post parturient period. This period, where a series of metabolic alterations appears, including the fatty liver syndrome, is well-known to be critical in regard to a number of diseases (Reid 1982). In 1968 Cordes \& Shortridge stated that metabolic changes associated with pregnancy may predispose cattle to sy- 
stemic mycosis. The pregnancy status of cattle in this survey seems to point out the post parturient period as the period in which cattle are most susceptible to mycotic infections. This might be due to metabolic changes combined with the stressors of calving, starting lactation and receiving higher and new ration. This view is in agreement with that of Damodaran et al. (1976).

All mycotic infections in this survey were undiagnosed until the post-mortem examination, because mycotic infections produce quite unspecific symptoms, such as diarrhoea, fever, melaena and apathy. These signs could represent a lot of intestinal illnesses. Another difficulty in diagnosing systemic mycosis is that its symptoms may be masked by the expressions of the underlying disease. Of the 23 cases described, a main diagnosis of mycosis was only established in 5 cases (numbers 5, 7, 8, 10 and 19). In the remaining 18 cases the mycotic infection was regarded to have had a minor importance in the total necropsy result.

Attempts to use precipitating antibody systems for identifying cattle which have, or have had, systemic mycosis have been made several times, with variable success (Corbel 1972, Knudtson et al. 1974, Wiseman et al. 1984, Schønheyder \& Jensen 1988).

From the histological examination it may be deduced that the central area in the acute lesions are arteriovenous haemorrhagic infarcts caused by a thrombogenic pathogenesis. The demarcation zone is characterized by haemorrhage, a pronounced infiltration of heterophilic granulocytes and necrosis. Around hyphae, outside central necrotic areas, substantial tissue necrosis only became apparent subsequent to infiltration by heterophilic granulocytes. These findings lead to the assumption that the release of enzymes from the migrated granulocytes is important in the formation of this necrosis.
The release of enzymes from heterophilic granulocytes has been shown to be important in thrombus formation in aspergillosis in cattle (Housted 1976).

In case number 14 Aspergillus fumigatus was isolated from liver tissue, although histological examination of several tissue specimens revealed no mycotic affections. If these findings were not due to contamination, the positive cultivation might have resulted from germination of spores carried in macrophages. The latter situation is thought to constitute a hazard, especially during pregnancy (Cordes et al. 1964a).

The indirect immunofluorescence technique used in this study has been described in detail elsewhere (Jensen \& Schønheyder 1989). In that paper, comparison of results of identification based on morphology, cultivation and immunofluorescence technique has been discussed.

In 2 surveys of laminae in the omasum of randomly selected slaughterhouse cattle, Brownlee \& Elliot (1960) and Jensen (1987), respectively, found epithelialized fenestrations in $15.9 \%$ and $16.1 \%$ of the material. In none of these surveys the histological examination revealed evidence of a mycotic infection. In view of the histological findings of subacute and chronic mycotic omasal infections in the present study, it is reasonable to assume that at least some of the cases of Brownlee \& Elliot, and Jensen have had a mycotic aetiology despite the fact that no hyphae were found histologically in the edges of the fenestrations.

That mycotic infections in the forestomach compartments of healthy slaughtherhouse cattle do occur was confirmed by the authors in another survey (unpublished) comprising 40 randomly collected slaughterhouse cattle. In that material, 1 case of chronic mycotic infection was found in a single omasal lamina. Macroscopically it had the appearance 
of a depapillated scar. When comparing the results obtained by Brownlee \& Elliot (1960) and Jensen (1987) with those of the present study, the difference in examining selected material contra randomly collected material is obvious. This is presumably a reflection of the previously described importance of predisposing factors in fungal infections.

The massive hyphal infiltration in thrombosed vessels, especially veins, and the fact that both histological and mycological examination of several lymph nodes failed to reveal fungi support the hypothesis that the blood system is the major route of local and systemic spread of fungi in systemic mycosis (Watanabe et al. 1979, Cordes \& Shortridge 1968, Nayak et al. 1975). In this study that view is further supported by revealing the liver to be the most frequently infected organ outside the stomachs.

\section{References}

Ainsworth GC, Austwick PKC: Fungal Diseases of Animals. 2nd ed. C.A.B. 1973.

Angus KW, Gulmour NJL, Dawson CO: Alimentary mycotic lesions in cattle: a histological and cultural study. J. med. Microbiol. 1973, 6, 207-213.

Anon. Ann. Rep. vet. Res. Lab., Department of Agriculture, Dublin 1971-72, p. 36-37.

Austwick PKC: The presence of Aspergillus fumıgtus in the lungs of dairy cows. Lab. Invest. 1962a, 11, 1065-1072.

Austwick PKC: Ecology of Aspergillus fumigatus and the pathogenic Phycomycetes. Recent Progress in Microbiology VIII, 1962b, 644-651.

Basse A: Bovine internal mycosis with special reference to the pathogenesis of aspergillosis. VIII International Meeting on Diseases of Cattle, Milan, 9th/13th September, 1974, p. 514-516.

Bendixen HC, Plum N: Skimmelsvampe (Aspergillus fumıgatus og Absıdia ramosa) som årsag til kastning hos kvæg. (Mould (Aspergillus fumigatus and Absidia ramosa) as causative agents in bovine abortion). Månedsskr. Dyrl. 1929, 41, 161-199, 209-240.
Brownlee A, Elliot J: Studies on the normal and abnormal structure and function of the omasum of domestic cattle. Brit. vet. J. 1960, 116, 467-473.

Chandler $F W$, Kaplan W, Ajello L: A Colour Atlas and Textbook of the Histopathology of Mycotic Diseases. Wolfe Medical Publications Ltd, 1980.

Chihaya Y, Matsukawa K, Mizushıma S, Matsul Y: Ruminant forestomach and abomasal mucormycosis under rumen acidosis. Vet. Pathol. 1988, 25, 119-123.

Corbel MJ: The serological response to Aspergillus fumıgatus antigens in bovine mycotic abortion. Brit. vet. J. 1972, 128, lxxiii-lxxv.

Cordes DO, Dodd DC, O'Hara PJ: Bovine mycotic abortion. N. Z. vet. J. 1964a, 12, 95-100.

Cordes DO, Dodd DC, O'Hare PJ: Acute mycotic pneumonia of cattle. N. Z. vet. J. 1964b, 12, 101104.

Cordes DO, Shortridge EH: Systemic phycomycosis and aspergillosis of cattle. N. Z. vet. J. 1968, 16, 65-80.

Cross RF, Moorhead PD, Jones JE: Candida albicans infection of the forestomachs of a calf. $\mathrm{J}$. Amer. vet. med. Assoc. 1970, 157, 1325-1330.

Damodaran S, Ramachandran PV, Thanıkachalam $M$, Mahalingam P: Mycotic gastritis in cattle. Indian vet. J. 1976, 53, 848-851.

Davis CL, Anderson WA, McCrory BR: Mucormycosis in foodproducing animals. A report of twelve cases. J. Amer. vet. med. Assoc. 1955, 126, 261-267.

Doherty ML, Markey BK: An unusual cause of anterior abdominal pain in a cow. Irish vet. J. 1987, 41, 281-285.

Eggert MJ, Romberg PF: Pulmonary aspergillosis in a calf. J. Amer. vet. med. Assoc. 1960, 137, 595596.

Emmons CW, Binford CH, Utz JP, Kwon-Chung KJ: Medical Mycology, 3rd ed. Lea \& Febiger, Philadelphia 1977.

Gitter M, Austwick PKC: The presence of fungi in abomasal ulcers of young calves: a report of seven cases. Vet. Rec. 1957, 69, 924-927.

Gleiser CA: Mucormycosis in animals. J. Amer. vet. med. Assoc. 1953, 123, 441-445.

Hatziolos BC: Systemic aspergillosis in a calf. Bull. Hellenic vet. med. Soc. 1973, 24, 75-86. 
Holtenius $P$, Nielsen $N$ : On the occurrence of nitrate and nitrite reducing fungi in the rumen of sheep. Nord. Vet.-Med. 1957, 9, 210-213.

Housted B: Undersøgelser over thrombogenesen ved eksperimentel aspergillose hos kvæg. (Investigation on the thrombosis in cattle with experimental aspergillosis). $27 \mathrm{pp}$. Licentiatafhandling (thesis). Department of Veterinary Pathology, The Royal Veterinary and Agricultural University, Denmark 1976.

Jensen HE: Patologiske fund i bladmaven hos kvæg. (Pathological findings in the omasum of cattle). Scandinavian Association for Veterinary Pathology. Annual meeting and symposium 11-12 June, 1987, Helsingfors, Finland. Suomen Elainlaakarilehti 1987, 93, 305-310.

Jensen $H E$ : Pato-anatomiske formavelæsioner hos kvæg. (Pathoanatomical lesions in the forestomachs of cattle). $151 \mathrm{pp}$. Licentiatafhandling (thesis). Department of Veterinary Pathology, The Royal Veterinary and Agricultural University, Denmark 1988.

Jensen $H E$, Schønheyder $H$ : Immunofluorescence staining of hyphae in the histopathological diagnosis of mycoses in cattle. J. med. vet. Mycol. 1989, 27, 33-44.

Kielstein P, Tausch I, Blaschke-Hellmessen R, Hubner $U$, Seebacher $C$, Ziegler-Bohme H: Zur Terminologie animaler Mykosen. (Terminology of mycoses in animals). Monatsh. Vet.-Med. 1987, 42, 176-178.

Knudtson WU, Kirkbride CA, Thurston JR: Bovine mycotic abortion: serology as an aid in diagnosis. Amer. Assn. Veterinary Laboratory Diagnosticians, 17th Annual Meeting, 1974, p. 299-303.

Krogh $H V$ : Bovine mycotic abortion in Denmark. Nord. Vet.-Med. 1985, 37, 27-33.

McCausland IP, Slee KJ, Hirst FS: Mycotic abortion in cattle. Aust. vet. J. 1987, 64, 129-132.

Miller RB: Mucormycosis associated with ruminitis. 9 Congres International sur les Maladies du Betail, Paris. Rapports et Resumes. Tome 2, 1976, p. 949-952.

Mills JHL, Hirth RS: Systemic candidiasis in calves on prolonged antibiotic therapy. J. Amer. vet. med. Assoc. 1967, 150, 862-870.
Munro R, Hunter AR, Bonniwell $M$, Corrigall $W$ : Systemic mycosis in Scottish red dear (Cervus elaphus). J. comp. Pathol. 1985, 95, 281-289.

Nayak BC, Rao AG, Ray SK, Chanda SK: Mycotıc ruminitis in a calf. Indian vet. J. 1975, 52, 55-57.

Neitzke JP, Schlefer B: Incidence of mycotic gastritis in calves up to 30 days of age. Can. vet. J. 1974, 15, 139-143.

Ohshima K, Miura S, Selmiya Y: Pathological studies on mucormycosis of the forestomach and abomasum in ruminants: a report on six cases complicated with candidiasis or pulmonary aspergillosis. Jap. J. vet. Sci. 1976, 38, 269-280.

Pinsent PJN, Ritchie HE: Ulceration of the abomasum in a Guernsey cow. Vet. Rec. 1955, 67, 769771.

Pohlenz J, Ehrensperger F, Breer C: Spontane Todesfalle infolge Mucormykose des Vormagens beim Rind. (Spontaneous death of cattle due to mucormycosis in the forestomachs). Schweiz. Arch. Tierheilk. 1973, 115, 161-168.

Reid IM: Liver function of high yielding dairy cows in early lactation. Proc. 12th World Buiatric Congr., 1982, p. 495-500.

Rolle $M$, Kolb E: Zur Frage des Vorkommens von Schimmelpilzen (Mucoraceae, Aspergillaceae) im Magen-Darmkanal der Haustiere. (On the occurrence of mould (Mucoraceae, Aspergillus spp.)) in the gastro-intestinal canal of domestic animals). Z. Hyg. Infektionskrankh. 1954, 139, 415-420.

Schiefer B: Pathomorphologie der Systemmykosen des Tieres. (Pathomorphology of systemic mycoses in animals). Fischer Jena. 1967.

Schønheyder $H$, Jensen $H E$ : Serum antibodies to the catalase antigen of Aspergillus fumigatus in cattle. Acta vet. scand. 1988, 29, 143-144.

Sheldon $W H$, Bauer $H$ : The role of predisposing factors in experimental fungus infections. Lab. Invest. 1962, 11, 1184-1191.

Sheridan JJ: The relationship of systemic phycomycosis and aspergillosis, in cattle showing signs of disease, to the occurrence of lesions in different organs. Vet. Res. Comm. 1981, 5, 1-12.

Smith T: Mycosis of the bovine fetal membranes due to a mould of the genus Mucor. J. exp. Med. $1920,31,115-122$. 
Thomson RG: Ruminitis in cattle. Can. vet. J. 1967, 8, 189-192.

Topolko S, Hajslg M, Karlovic M: Ruminitis in the calf caused by Candıda albicans. Vet. Arch. (Zagreb) 1967, 37, 205-207.

Watanabe K, Tabuchı K, Hara M, Kiuchi A, Sawaya $H$, Shımura S, Nomura $T$, Kobayashi $N$, Itoh $K$, Shinoda M, Miyashita I, Nomura Y, Tsuchiya T, Saito Y, Hoshino H: Mucormycosis due to Rhlzopus rhizopodiformis in animals: a report of 3 cases. Bull. Azabu Vet. Coll. 1979, 4, 25-32.

Werdin RE, Bates FY, Damer AT, Stowe CM: Diagnostic features of aspergillosis in a dairy herd. Amer. Assn. Veterinary Laboratory Diagnosticians, 23rd Annual Meetıng, 1980, p. 293-308.

Wiseman A, Dawson CO, Selman IE: The prevalence of serum precipitating antibody to Aspergillus fumigatus in adult cattle in Britain. J. comp. Pathol. 1984, 94, 535-542.

Wray C, Thomlinson JR: Abomasal ulceration in calves. Vet. Rec. 1968, 83, 80-81.

\section{Sammendrag}

Svampeinfektion i formaverne og loben hos kvaeg. I maverne fra kvæg seceret på Institut for Veterinær Patologi gennem en 22 måneders periode i 1986-87, fandtes systemiske mykoser i de $9,7 \%$ (23 af 238).
De forskellıge maveafsnit var afficeret i rækkefølgen: bladmave: 15 tilfælde; vom: 10 tilfælde; netmave: 8 tilfælde og løbe: 6 tilfælde. I 5 af tilfældene fandtes også mykotiske affektioner i andre organer, af disse var leveren oftest involveret.

Hoveddiagnosen "mykose « blev kun stillet i 5 af tilfældene. I de resterende tilfælde ansås de mykotiske affektioner for kun at have haft underordnet betydning, sammenlignet med de øvrige sektionsfund.

De mykotiske betændelser grupperedes makroskopisk og histologisk i typerne akutte, subakutte eller kroniske. I 20 tilfælde fandtes kun en type betændelse, i de øvrige fandtes kombinationer.

Identifikationen af de infektive svampe udførtes immunhistokemisk. Svampe tilhørende Zygomycetıdae fandtes oftest som causal organisme. Aspergillus fumigatus fandtes at have præference for de terminale maveafsnit, hvorimod Zygomycetidae fandtes ligeligt fordelt $\mathrm{i}$ maveafsnittene. I et tilfælde påvistes Candida spp.

Diverse prædisponerende faktorers betydning for etablering af systemiske mykoser diskuteres. De vigtigste af disse fandtes at være anvendelse af antibioti$\mathrm{ka} /$ kemoterapeutika, andre sygdomme samt metaboliske ændringer og stress i perioden efter kælvning.

(Recelved December 2, 1988; accepted January 25, 1989).

Reprints may be requested from: Henrik Elvang Jensen, Department of Veterinary Pathology, Royal Veterinary and Agricultural University, Bulowsvej 13, DK-1870 Frederiksberg C, Denmark. 
